\title{
Sociobiology
}

RESEARCH ARTICLE - TERMITES

\section{Effect of Termite on Soil pH and Its Application for Termite Control in Zhejiang Province, China}

\author{
$\mathrm{Y} \mathrm{LI}^{1,2}, \mathrm{ZY} \mathrm{DONG}^{3}, \mathrm{DZ} \mathrm{PAN}^{4}, \mathrm{CH} \mathrm{PAN}^{4}, \mathrm{LH}_{\mathrm{CHEN}}{ }^{4}$ \\ 1 - College of Chemical Engineering, Zhejiang University of Technology, Hangzhou, China \\ 2 - Zhejiang University of Water Resources and Electric Power, Hangzhou, China \\ 3 - College of Civil Engineering and Architecture, Zhejiang University of Technology, Hangzhou, China \\ 4 - Zhejiang Institute of Hydraulics and Estuary, Hangzhou, China
}

\section{Article History}

\section{Edited by}

Paulo F. Cristaldo, UFS, Brazil

Received

25 April 2017

Initial acceptance 14 June 2017

Final acceotance 11 August 2017

Publication date 17 October 2017

\section{Keywords}

Termite activity, soil characteristics, soil treatment, Odontotermes formosanus, Reticulitermes flaviceps.

\section{Corresponding author}

Dong-Zi Pan

Zhejiang Institute of Hydraulics and Estuary

50 East Fengqi Road - 310020

Hangzhou, China.

E-Mail: pandz@zjwater.gov.cn.

\begin{abstract}
Soil dwelling termites dig nests in the ground that have a significant impact on the soil environment. Activities of termites can result in accumulation of organic matter and enrichment of nutrients and minerals in the soil. Samples from the nest/ surrounding soils of two termite species (Odontotermes formosanus (Shiraki) and Reticulitermes flaviceps (Oshima)) and termite non-invaded soils in the seawall of the Qiantang River, Zhejiang Province, China were collected and analysed for soil $\mathrm{pH}$. The results show that the observed termites prefer an acidic environment and that their activities elevate the $\mathrm{pH}$ of termite mound soil compared with surrounding soil. Considering the differences in the distribution areas, termite species, and properties of termite mounds and surrounding soils, this paper also examines the literature concerning the effects of termites on soil pH. After summarizing the $\mathrm{pH}$ of the termite survival soil environment, the feasibility of termite control by modifying the soil $\mathrm{pH}$ is addressed. Finally, some topics for future research are discussed.
\end{abstract}

\section{Introduction}

Termites are considered to be an important asset in the soil ecosystem; their activities alter the soil $\mathrm{pH}$, organic carbon content, water content and void ratio (Lee \& Wood, 1971; Nutting et al., 1987; de Bruyn \& Conacher, 1990; Asawalam et al., 1999; Sarcinelli et al., 2009). However, termites have become a serious menace to both plants and structures. Housing constructions, dams and reservoirs, and agricultural fields are vulnerable to termite attack (Su \& Scheffrahn, 1998; Verma et al., 2009; Tian et al., 2009). Termites have caused an annual economic loss of over 1000 million dollars and 250-300 million dollars in the USA and China, respectively (Verma et al., 2009). Effective methods have been taken to control termites, including physical, chemical, biological and bait technologies $(\mathrm{Su} \&$ Scheffrahn, 1998; Su, 2002). Termite control using saline soil is a novel technology that was recently developed in China.
It has been applied in Safety Assurance of 1000 Reservoirs Projects in Zhejiang Province (Chen, 2002; Chen et al., 2011). However, this method fails to supply complete knowledge of the underlying mechanism.

Odontotermes formosanus (Shiraki) and Reticulitermes flaviceps (Oshima) are two dominant termite species that destroy earthen seawall of the Qiantang River, Zhejiang Province, China. Published studies presenting effect of termites on soil properties are numerous (reviews by de Bruyn \& Conacher, 1990; Robert, 2007; Neupane, 2015). However, little information is available in the literature on the quantitative description of Odontotermes formosanus (Shiraki) and Reticulitermes flaviceps (Oshima) affect soil $\mathrm{pH}$. The objectives of the present study were therefore to (1) evaluate the influence of soil $\mathrm{pH}$ resulting from activities of the observed termites, and (2) probe the feasibility of termite control using saline soil in terms of soil $\mathrm{pH}$ modification. 


\section{Materials and Methods}

Methods

To achieve the study objectives, we (1) surveyed the termite nest at the study site, (2) collected samples from the termite nest/surrounding soils and termite non-invaded soils, (3) measured the soil $\mathrm{pH}$ in the laboratory, and (4) compared the results with the literature concerning the effects of termites on soil $\mathrm{pH}$.

\section{Study field}

The study was conducted in the region of the seawall of Qiantang River, Zhejiang Province, China (Fig1), where the climate is subtropical and humid. This area has an average annual rainfall of approximately $1200 \mathrm{~mm}$ and an average annual daily temperature of approximately $16{ }^{\circ} \mathrm{C}$. In 2000 , inspectors first discovered and verified a termite infestation in the ancient seawall. The nest materials of two termite species, Odontotermes formosanus (Shiraki) and Reticulitermes flaviceps (Oshima), and their surrounding soils were collected and analyzed in terms of $\mathrm{pH}$ in the present work.

\section{Soil sampling and $\mathrm{pH}$ analysis}

Soil sampling at two main types of seawall is sketched in Fig 1b (Stone seawall) and Fig 1c (Slope seawall). The termite nests were excavated, and soil sampling was carried out at different positions, ranging from top to the bottom of the nest, and then pooled into a single sample. The adjacent surrounding soil without termite activity was also sampled within $2 \mathrm{~m}$ of the central of the nest. The $\mathrm{pH}$ determinations were carried out in a $1: 2.5$ soil to water mixture using a pH-meter (Ministry of Agriculture of the People's Republic of China, 2007).

\section{Statistical analyses}

Statistical Product and Service Solutions (SPSS, 2007) was used for statistical test. Paired sample $t$-test was used to determine significant differences between $\mathrm{pHs}$ of the nest material and the surrounding soils.

\section{Results}

pH of the termite nest/surrounding soils

The material of seawall filling soil is mainly composed of silty clay. Most termite infestations are caused by Odontotermes formosanus (Shiraki) and Reticulitermes flaviceps (Oshima). The $\mathrm{pH}$ of the nest materials were higher than that of the surrounding soils $(P<0.05)$ (Tables 1,2$)$. In general, the nest materials of Reticulitermes flaviceps (Oshima) have been found to have higher $\mathrm{pH}$ values than the nest materials of Odontotermes formosanus (Shiraki).

\section{pH of the termite non-invaded soils}

No termites were detected in the following areas (Fig 1): (1) a seawall constructed of saline soil after the 1960s, such as in Hezhuang; (2) a seawall reinforced using saline soil, such as in Laoyanchang, which was collected from an intertidal zone; (3) a seawall that had been showered by an inflow of seawater due to a storm surge, such as in Dushan. The salinity

(a)

(b)

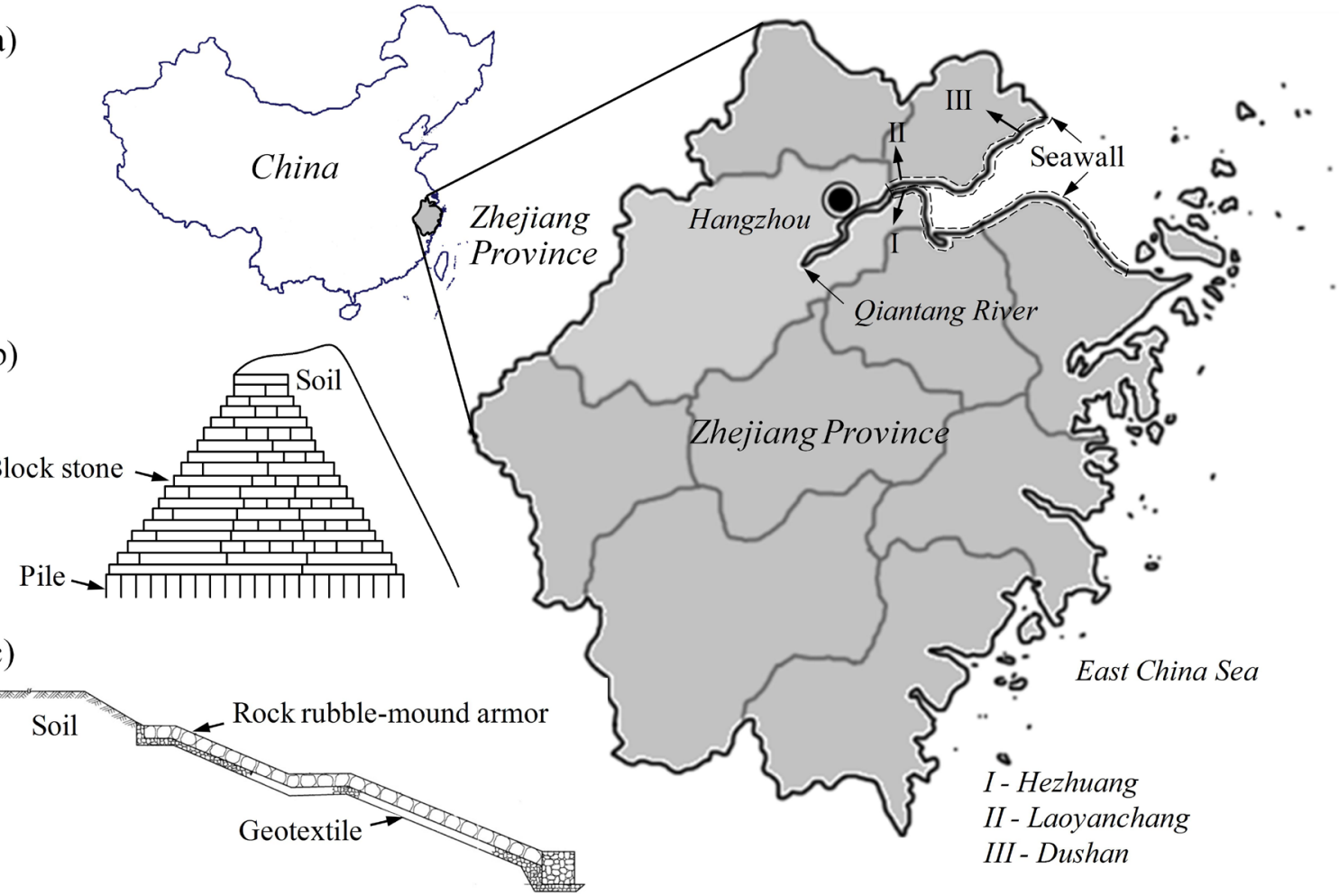

Fig 1. Study site. (a) Location of the Qiantang River in China; (b) Stone seawall; (c) Slope seawall. 
Table 1. $\mathrm{pH}$ of termites nest materials and the surrounding soils.

\begin{tabular}{|c|c|c|c|c|c|c|}
\hline Specie & Sampling site & $\mathrm{TN}$ & SS & TN-SS & T-Value & $\mathrm{n}$ \\
\hline \multirow{2}{*}{$\begin{array}{l}\text { Odontotermes } \\
\text { formosanus (Shiraki) }\end{array}$} & Stone seawall & $6.52( \pm 0.36)[6.07-7.19]$ & $6.10( \pm 0.16)[5.85-6.47]$ & 0.43 & $3.25 *$ & 10 \\
\hline & Slope seawall & $6.44( \pm 0.29)[6.03-7.08]$ & $6.06( \pm 0.19)[5.81-6.42]$ & 0.38 & $3.04 *$ & 10 \\
\hline $\begin{array}{l}\text { Reticulitermes } \\
\text { flaviceps (Oshima) }\end{array}$ & Slope seawall & $6.86( \pm 0.39)[6.53-7.74]$ & $6.14( \pm 0.30)[5.71-6.76]$ & 0.71 & $3.60 *$ & 10 \\
\hline
\end{tabular}

TN: Termite nest, SS: Surrounding soil.* Significant at the $5 \%$ level $(\mathrm{P} \leq 0.05)$. Values are mean $( \pm \mathrm{SD})[$ minimum-maximum]. SD: Standard deviation.

of the seawater is approximately $1 \%$. The results for the $\mathrm{pH}$ of the termite non-invaded soils are presented in table 2.The $\mathrm{pH}$ values of the termite non-invaded soils ranged from 8.12 to 8.94 , which was far higher than the values of the termite nest/ surrounding soils.

\section{Discussion}

Considering the differences in the distribution areas, termite species, and properties of termite mounds and surrounding soils, we also summarized $\mathrm{pH}$ test studies in the peer-reviewed, scientific literature and found 117 results published in 51 papers (Table 3). Statistically, most termites nested in acidic and weakly alkaline soils, with surrounding soils $\mathrm{pH}$ values between 3.5 and 8.7 (Fig 2a). Of 117 sets of data, $84 \%$ showed surrounding soils $\mathrm{pH}$ values lower than 7 , with an average of 5.7. $\mathrm{pH}$ values from 4.5 to 5.5 demonstrated the highest frequency band in surrounding soils, covering $38 \%$. Thus, the results supported a preference of most termites for an acidic soil environment. The $\mathrm{pH}$ values of termite mounds within this range (Fig 2b), however, had a higher average value (6.2). The frequency dis-
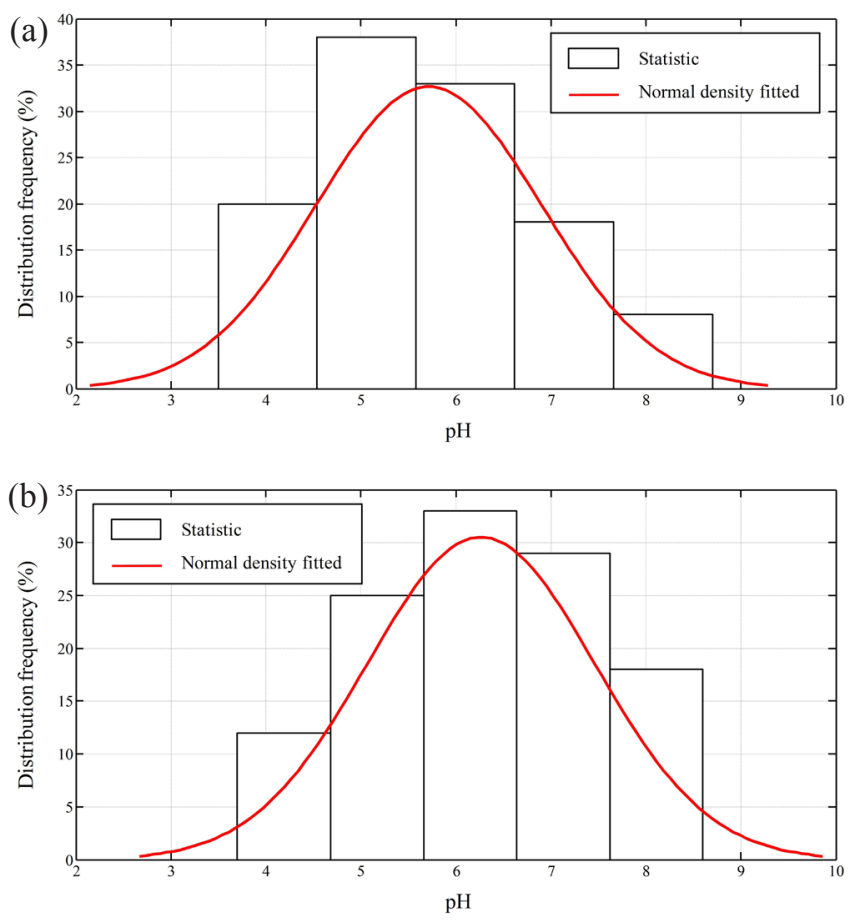

Fig 2. $\mathrm{pH}$ frequency distributions of surrounding soils and termite mounds. (a) Surrounding soils; (b) Termite mounds. tribution of $\mathrm{pH}$ value differences (D-Value) between termite mounds and surrounding soils are presented in Fig 3. Among the data, $76 \%$ showed increases in $\mathrm{pH}$ caused by the activities of termites. A pH value difference ranging from 0 to 0.5 demonstrated the highest frequency band statistically, covering $48 \%$.

Consistent with previous literature analysis, termite nest material and surrounding soils are considered to be slightly acidic in the seawall of Qiantang River. In the termite non-invaded areas, the $\mathrm{pH}$ of the seawall filling had a higher value. Therefore, an increase in soil $\mathrm{pH}$ might lead to termite inactivation. In practice, irrigating with seawater on the inside slope (Fig 4a), covering a saline soil mixture on the slope (Fig 4b) or filling the saline soil in the seawall (Fig 4c) could reduce termite infestation. In China, a method to increase the $\mathrm{pH}$ of dike fillings with saline soils is shown in Fig 5.

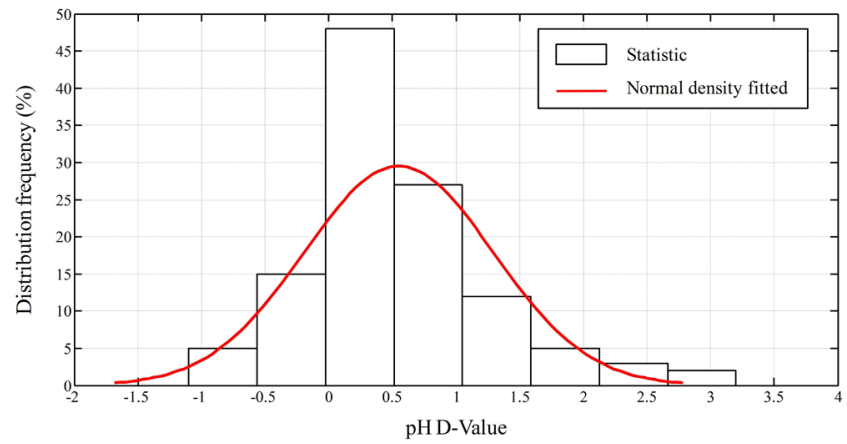

Fig 3. Frequency distribution of $\mathrm{pH}$ difference-values (D-Value) between termite mounds and surrounding soils.

In this method, a well with a diameter of $0.5 \mathrm{~m}$ is created though the seepage line of the dike (Fig $5 b$ ) and then backfilled with salt-mixed soils at a salt/soil ratio of $0.08 \%$ (Fig $5 \mathrm{c}$ ). This method is easy to setup and perform, and the effectiveness of the termite control period can reach 20 years (Chen, 2002).

Nevertheless, negative effects may be incurred from the addition of saline soil as a termite control measure. The physical properties of the mixed soil would change compared with the original soil. An appropriate amount of salt had no obvious effect on the soil permeability. However, the coefficient of water-soluble salts of the soil clearly increased. In addition, the soil shear strength and compression modulus would decrease with the rise in soil salinity (Chen et al., 2015). Furthermore, termites are not the only organisms living in the environment, so all other organisms would be affected by the saline soil. 
Table 2. $\mathrm{pH}$ of the termite non-invaded soils $(\mathrm{n}=10)$.

\begin{tabular}{cc}
\hline Sampling site & $\mathrm{pH}$ \\
\hline Stone seawall & $8.46( \pm 0.19)[8.28-8.94]$ \\
Slope seawall & $8.51( \pm 0.25)[8.12-8.85]$ \\
\hline
\end{tabular}

Values are mean $( \pm \mathrm{SD})$ [minimum - maximum]. SD: Standard deviation.

\section{Conclusions}

The present study provides evidence that the activities of Odontotermes formosanus (Shiraki) and Reticulitermes flaviceps (Oshima) significantly influence the soil $\mathrm{pH}$ and that a soil $\mathrm{pH}$ increase may lead to termite inactivation. Further research should include the following topics: (1) During development, termite nests undergo many processes; therefore, the variability of the soil $\mathrm{pH}$ during different periods must be considered; (2) different species of termites have different
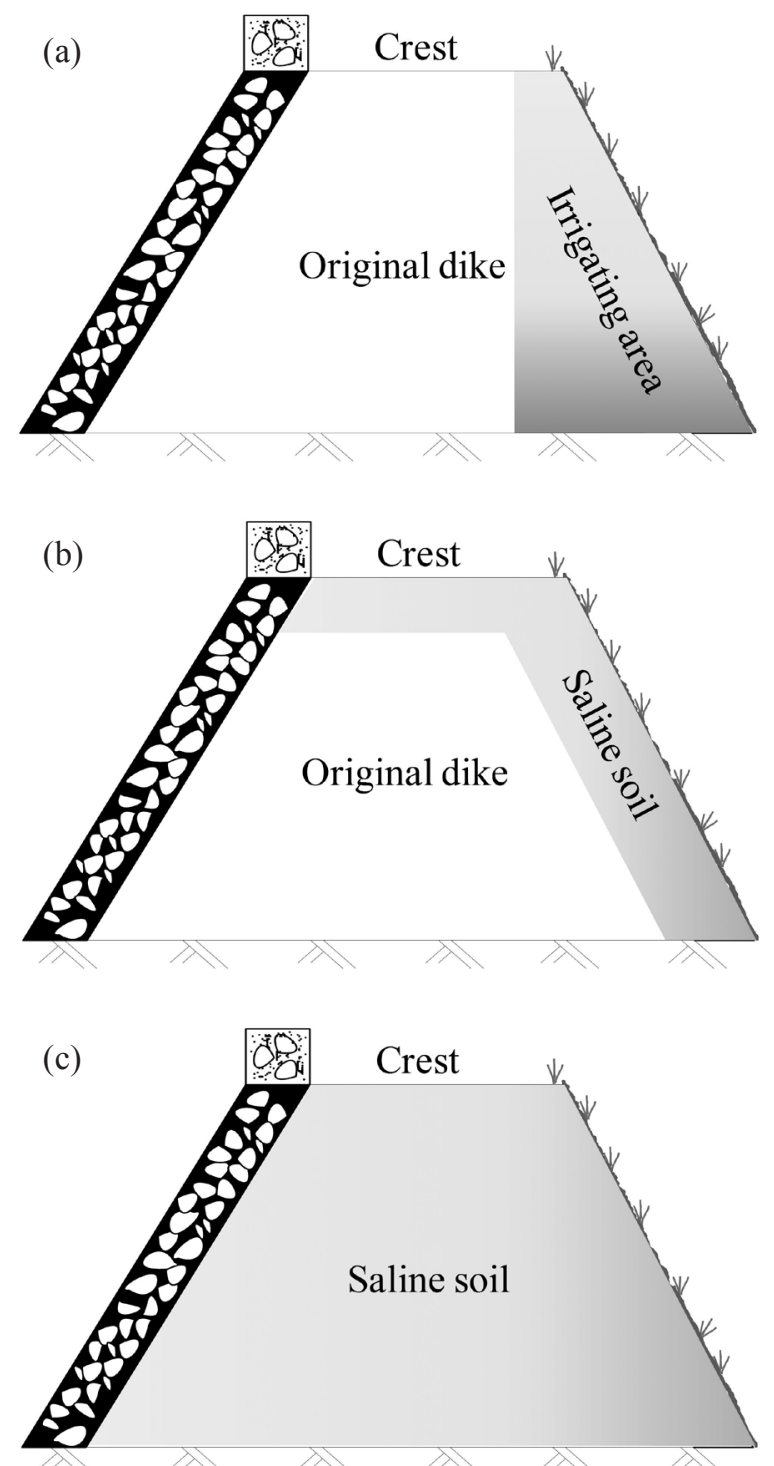

Fig 4. Methods for increasing the soil $\mathrm{pH}$ of seawall. (a) Seawater irrigation; (b) Saline soil covering; (c) Saline soil filling.

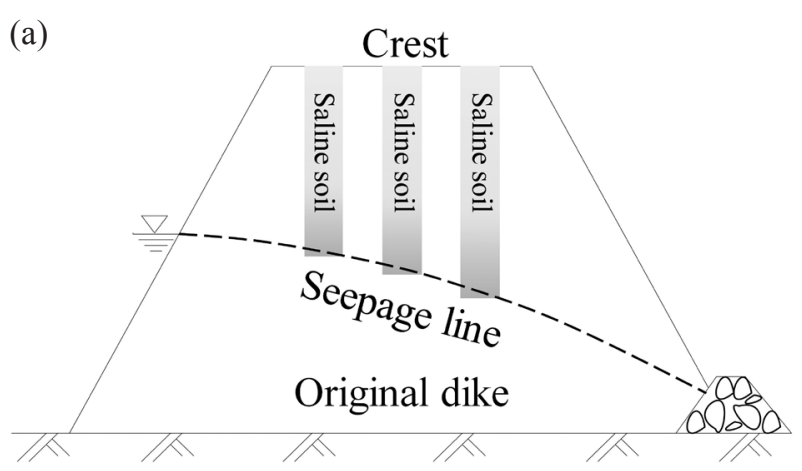

(b)

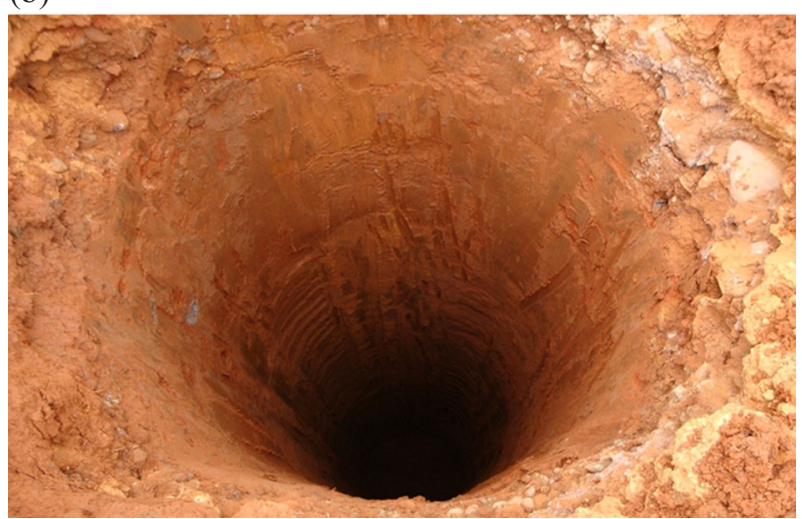

(c)

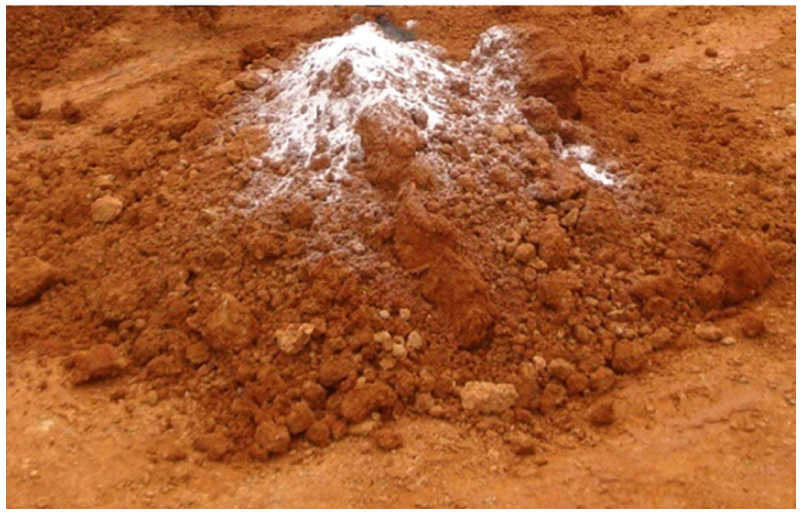

Fig 5. Site operation of termite control with saline soil. (a) Sketch diagram; (b) Dig wells; (c) Backfill with salt mixed soils.

preferences regarding selection of a nest soil environment, and the progress of related studies is still in its infancy; (3) the maneuverability, effectiveness and durability of termite control by using saline soil need to be better understood.

\section{Acknowledgments}

The authors gratefully acknowledge the comments provided by two anonymous reviewers. This study was partially funded by the Key Science and Technology Special Project of Zhejiang Province (Grant No. 2011C13045).

\section{Authors contribution}

$\mathrm{Y} \mathrm{Li}$ and LH Chen contributed to the conception of the study and manuscript preparation; Y Li and DZ Pan performed the data analyses and wrote the manuscript; ZY Dong and $\mathrm{CH}$ Pan helped perform the analysis with constructive discussions. 
Table 3. Summary for the pHs of termite mounds (TM) and surrounding soils (SS) from literature.

\begin{tabular}{|c|c|c|c|c|c|}
\hline \multirow{2}{*}{ Location } & \multirow{2}{*}{ Reference } & \multirow{2}{*}{ Species } & \multicolumn{3}{|c|}{ Soil pH* } \\
\hline & & & $\mathrm{TM}$ & SS & DV \\
\hline \multirow[t]{7}{*}{ Kenya } & Robinson, 1958 & Odontotermes badius (Haviland) & 5.89 & 5.52 & 0.37 \\
\hline & Bagine, 1984 & Odontotermes sp. & 7.9 & 8.6 & -0.7 \\
\hline & Arshad et al., 1988 & Macrotermes michaelseni & 7.1 & 6.0 & 1.1 \\
\hline & & Macrotermes michaelseni & 6.1 & 5.7 & 0.4 \\
\hline & & Macrotermes herus & 7.2 & 5.5 & 1.7 \\
\hline & & Macrotermes herus & 7.9 & 6.1 & 1.8 \\
\hline & & Macrotermes herus & 5.8 & 5.5 & 0.3 \\
\hline \multirow[t]{6}{*}{ Zimbabwe } & Watson, 1962 & sp. & $7.91( \pm 0.85)$ & $6.16( \pm 0.55)$ & 1.75 \\
\hline & Watson, 1969 & Odontotermes badius (Haviland) & 5.7 & 4.4 & 1.3 \\
\hline & & sp. & 7.2 & 4.9 & 2.3 \\
\hline & Watson, 1972 & Macrotermes natalensis (Haviland) & 5.8 & 4.3 & 1.5 \\
\hline & Watson, 1977 & Macrotermes falciger (Gerstäcker) & 7.4 & 5.0 & 2.4 \\
\hline & Muvengwi et al., 2013 & Macrotermes.sp. & $7.5( \pm 0.1)$ & $5.8( \pm 0.2)$ & 1.7 \\
\hline \multirow[t]{24}{*}{ Nigeria } & Nye, 1955 & Macrotermes nigeriensis (Sjöst) & $6.83( \pm 0.39)$ & $6.60( \pm 0.17)$ & 0.23 \\
\hline & & Macrotermes nigeriensis (Sjöst) & $6.83( \pm 0.31)$ & $5.88( \pm 0.69)$ & 0.95 \\
\hline & Malaka, 1977 & Amitermes evuncifer & 4.6 & 4.2 & 0.4 \\
\hline & & Cubitermes sp. & 4.7 & 4.4 & 0.3 \\
\hline & & Macrotermes bellicosus & 4.5 & 4.7 & -0.2 \\
\hline & & Trinervitermes geminatus & 5.1 & 4.7 & 0.4 \\
\hline & Wood et al., 1983 & Cubitermes ocularus (Silvestri) & $5.9( \pm 0.12)$ & $6.0( \pm 0.11)$ & -0.1 \\
\hline & & Cubitermes severus (Silvestri) & $6.0( \pm 0.07)$ & $5.3( \pm 0.03)$ & 0.7 \\
\hline & Akamigbo, 1984 & Nasutitermes sp. & 5.3 & 4.9 & 0.4 \\
\hline & Andorcon \& Whod 1081 & Cubitermes severus & 6.0 & 5.3 & 0.7 \\
\hline & Alluersont a wood, 1904 & Procubitermes aburiensis & 5.5 & 4.9 & 0.6 \\
\hline & Ezenwa, 1985 & Macrotermes bellicosus & 6.3 & 5.8 & 0.5 \\
\hline & & Trinervitermes geminatus & 6.3 & 5.7 & 0.6 \\
\hline & Asawalam et al., 1999 & Nasutitermes sp. & 5.1 & 4.2 & 0.9 \\
\hline & Ahe \&Wakatsuki 2010 & Macrotermes bellicosus & $6.8( \pm 1.3)$ & $5.8( \pm 0.6)$ & 1.0 \\
\hline & 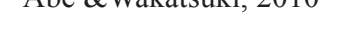 & Macrotermes bellicosus & $5.8( \pm 0.2)$ & $6.2( \pm 0.9)$ & -0.4 \\
\hline & & Macrotermes bellicosus & $7.2( \pm 0.4)$ & $6.3( \pm 0.4)$ & 0.9 \\
\hline & Afolabi et al., 2014 & Macrotermes bellicosus & 6.72 & 6.62 & 0.1 \\
\hline & & Trinervitermes geminatus & 6.33 & 6.33 & 0.0 \\
\hline & Ehigiator et al., 2015 & $\mathrm{sp}$. & 5.9 & 4.9 & 1.0 \\
\hline & & sp. & 5.8 & 4.8 & 1.0 \\
\hline & & sp. & 6.1 & 4.9 & 1.2 \\
\hline & & $\mathrm{sp}$. & 6.1 & 4.7 & 1.4 \\
\hline & & sp. & 6.2 & 5.1 & 1.1 \\
\hline \multirow[t]{8}{*}{ Congo } & Garnier-Sillam & Noditermes lamanianus & $4.8( \pm 0.2)$ & $4.1( \pm 0.3)$ & 0.7 \\
\hline & \& Harry, 1995 & Cubitermes fungifaber & $4.8( \pm 0.3)$ & $4.1( \pm 0.3)$ & 0.7 \\
\hline & & Thoracotermes rnacrothorax & $4.5( \pm 0.3)$ & $4.1( \pm 0.3)$ & 0.4 \\
\hline & & Crenetermes albotarsalis & $3.7( \pm 0.1)$ & $4.1( \pm 0.3)$ & -0.4 \\
\hline & Mujinya et al., 2010 & Macrotermes sp. & $6.4( \pm 1.39)$ & $5.0( \pm 0.01)$ & 1.4 \\
\hline & Mujinya et al., 2011 & Macrotermes sp. & 8.0 & 4.8 & 3.2 \\
\hline & & Macrotermes sp. & 8.6 & 6.0 & 2.6 \\
\hline & Erens et al., 2015 & Macrotermes falciger & $8.11( \pm 0.1)$ & $5.21( \pm 0.16)$ & 2.9 \\
\hline
\end{tabular}


Table 3. Summary for the pHs of termite mounds (TM) and surrounding soils (SS) from literature. (Continuation)

\begin{tabular}{|c|c|c|c|c|c|}
\hline \multirow{2}{*}{ Location } & \multirow{2}{*}{ Reference } & \multirow{2}{*}{ Species } & \multicolumn{3}{|c|}{ Soil $\mathrm{pH}^{*}$} \\
\hline & & & $\mathrm{TM}$ & SS & DV \\
\hline Uganda & Okwakol, 1987 & Cubitermes testaceus (Williams) & $5.5( \pm 0.3)$ & $4.7( \pm 0.1)$ & 0.8 \\
\hline \multirow{4}{*}{ Tanzania } & & sp. & 7.12 & 5.59 & 1.53 \\
\hline & Ketch et al., 2001 & Macrotermes sp. & 6.4 & 5.4 & 1.0 \\
\hline & & Macrotermes sp. & 6.1 & 5.3 & 0.8 \\
\hline & & Macrotermes sp. & 4.7 & 4.4 & 0.3 \\
\hline \multirow[t]{3}{*}{ Cameroon } & Donovan et al., 2001 & Cubitermes fungifaber & 4.26 & 4.08 & 0.18 \\
\hline & & Cubitermes fungifaber & 5.02 & 4.51 & 0.51 \\
\hline & & Cubitermes fungifaber & 5.77 & 5.52 & 0.25 \\
\hline \multirow[t]{3}{*}{ Gabon } & Roose-Amsaleg et al., 2004 & Cubitermes sp. & $5.3( \pm 0.5)$ & $4.9( \pm 0.2)$ & 0.4 \\
\hline & Roose-Amsaleg et al., 2005 & Cubitermes sp. & $5.41( \pm 0.37)$ & $4.64( \pm 0.34)$ & 0.77 \\
\hline & Jouquet et al., 2005 & Ancistrotermes cavithorax (Sjöstedt) & $6.64( \pm 0.2)$ & $6.53( \pm 0.32)$ & 0.11 \\
\hline \multirow[t]{2}{*}{ Côte d'Ivoire } & & Ancistrotermes cavithorax (Sjöstedt) & $7.06( \pm 0.64)$ & $6.82( \pm 0.3)$ & 0.24 \\
\hline & & Odontotermes nrpauperans (Silvestri) & $6.92( \pm 0.39)$ & $6.82( \pm 0.3)$ & 0.1 \\
\hline \multirow[t]{2}{*}{ Burkina Faso } & Brossard et al., 2007 & Trinervitermes geminatus & $6.7( \pm 0.5)$ & $6.6( \pm 0.6)$ & 0.1 \\
\hline & & Trinervitermes trinervius & $6.9( \pm 0.7)$ & $6.4( \pm 0.3)$ & 0.5 \\
\hline \multirow[t]{6}{*}{ Venezuela } & Salick et al., 1983 & sp. & 3.9 & 3.9 & 0.0 \\
\hline & & sp. & 4.3 & 3.5 & 0.8 \\
\hline & López-Hernández & Cubitermes sp. & 6.7 & 5.7 & 1.0 \\
\hline & \& Febre, 1984 & Macrotermesbellicosus & 6.1 & 5.8 & 0.3 \\
\hline & & Trinervitermes geminatus & 7.3 & 6.5 & 0.8 \\
\hline & López-Hernández, 2001 & Nasutitermes ephratae & 5.6 & 4.8 & 0.8 \\
\hline \multirow[t]{2}{*}{ USA } & Nutting et al., 1987 & Gnathamitermes perplexus (Banks) & 7.6 & 6.8 & 0.8 \\
\hline & & Heterotermes aureus (Synder) & 7.9 & 6.8 & 1.1 \\
\hline \multirow[t]{10}{*}{ Brazil } & Fageria \& Baligar, 2004 & sp. & 5.7 & 5.4 & 0.3 \\
\hline & Kaschuk et al., 2006 & sp. & $4.83( \pm 0.31)$ & $4.55( \pm 0.07)$ & 0.28 \\
\hline & & sp. & $4.27( \pm 0.15)$ & $4.10( \pm 0.01)$ & 0.17 \\
\hline & & sp. & $5.07( \pm 0.21)$ & $5.23( \pm 0.22)$ & -0.16 \\
\hline & & sp. & $4.73( \pm 0.43)$ & $4.48( \pm 0.08)$ & 0.25 \\
\hline & & sp. & $4.80( \pm 0.33)$ & $4.68( \pm 0.03)$ & 0.12 \\
\hline & Ackerman et al., 2007 & sp. & 4.3 & 4.4 & -0.1 \\
\hline & Sarcinelli et al., 2009 & sp. & 4.23 & 3.89 & 0.34 \\
\hline & & sp. & 4.99 & 3.98 & 1.01 \\
\hline & & sp. & 4.96 & 4.19 & 0.77 \\
\hline
\end{tabular}


Table 3. Summary for the pHs of termite mounds (TM) and surrounding soils (SS) from literature. (Continuation)

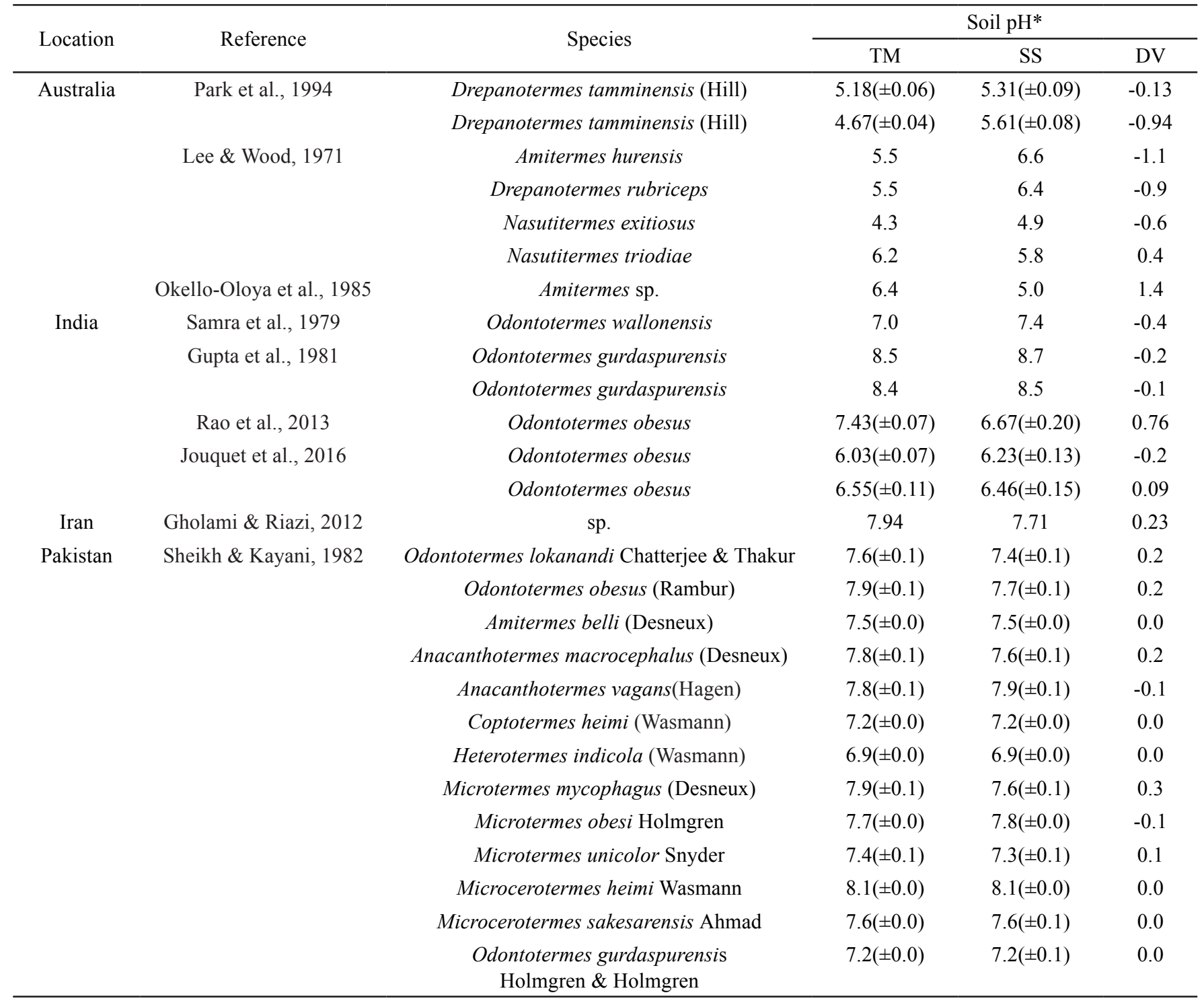

* Values are mean $( \pm \mathrm{SD}), \mathrm{SD}$ : Standard deviation, sp.: species unknown.

TM: Termite mound, SS: Surrounding soil, DV: $\mathrm{pH}$ difference valuebetween TM and SS.

\section{References}

Abe, S.S. \& Wakatsuki, T. (2010). Possible influence of termites (Macrotermes bellicosus) on forms and composition of free sesquioxides in tropical soils. Pedobiologia, 53: 301-306. doi: 10.1016/j.pedobi.2010.02.002.

Ackerman, I.L., Teixeira, W.G., Riha, S.J., Lehmann, J. \& Fernandes, E.C.M.(2007). The impact of mound-building termites on surface soil properties in a secondary forest of Central Amazonia. Applied Soil Ecology, 37: 267-276. doi: 10.1016/j.apsoil.2007.08.005.

Afolabi, S.G., Ezenwa, M.I.S. \& Dauda, A. (2014). Physical and chemical characteristics of mound materials and surrounding soils. PAT, 10: 186-192. Retrieved from: www.patnsukjournal.net/currentissue.
Akamigbo, F. (1984). The role of the Nasute termites in the genesis and fertility of Nigerian soils. Pedologie, 36: 79-89.

Anderson, J.M. \& Wood, T.G. (1984). Mound composition and soil modification by two soil-feeding termites (Termitinae, Termitidae) in a riparian Nigerian forest. Pedobiologia, 26: 77-82.

Arshad, M.A. (1982). Influence of the termite Macrotermes michaelseni (Sjöst) on soil fertility and vegetation in a semi-arid savannah ecosystem. Agro-Ecosystems, 8: 47-58. doi: 10.1016/0304-3746(82)90014-2.

Arshad, M.A., Schnitzer, M. \& Preston, C.M. (1988). Characterization of humic acids from the termite mounds and surrounding soils, Kenya. Geoderma, 42: 213-225. doi: 10.1016/ 0016-7061(88)90002-X.

Asawalam, D.O., Osodeke, V.E., Kamalu, O.J. \&Ugwa, I.K. 
(1999). Effects of termites on the physical and chemical properties of the acid sandy soils of southern Nigeria.Communications in Soil Science and Plant Analysis, 30: 1691-1696. doi: 10.1080/00103629909370321.

Bagine, R.K.N. (1984). Soil translocation by termites of the genus Odontotermes (Holgren) (Isoptera: Macrotermitinae) in an arid area of northern Kenya. Oecologia, 64: 263-266. doi: 10.1007/BF00376880.

Brossard, M.,López-Hernández, D., Lepage, M. \& Leprun, J. C. (2007). Nutrient storage in soils and nests of mound-building Trinervitermes termites in Central Burkina Faso: consequences for soil fertility. Biology and Fertility of Soils, 43: 437-447. doi: 10.1007/s00374-006-0121-6.

Chen, L.H. (2002). Cause and control of termite infestation at the northern seawall of Qiantang River. Zhejiang Hydrotechnics, 2: 34-35.

Chen, L.H., Pan, C.H., Chen, S.M., Song, X.G., Zheng, S.Z. \& Chen, S.H.(2011). New technology of using salt to prevent termites for dikes and dams. Chinese Journal of Geotechnical Engineering, 33: 140-144.

Chen, S.-H., Shen, S.-J., Chen, L.-H. \& Lu, G.-X. (2015). Test of engineering properties of impervious soil with salt. Advances in Science and Technology of Water Resources, 35: 66-70.

Dawes, T.Z. (2010). Reestablishment of ecological functioning by mulching and termite invasion in a degraded soil in an Australian savanna. Soil Biology and Biochemistry, 42: 1825-1834. doi: 10.1016/j.soilbio.2010.06.023.

Debelo, D.G. \& Degaga, E.G. (2014). Studies on ecology of mound-building termites in the central rift valley of Ethiopia. International Journal of Agricultural Sciences, 4: 326-333.

de Bruyn, L.L.A. \& Conacher, A.J. (1990). The role of termites and ants in soil modification: a review. Australian Journal of Soil Research, 28: 55-93. doi: 10.1071/SR9900055.

Donovan, S.E., Eggleton, P., Dubbin, W.E., Batchelder, M. \& Dibog, L.(2001). The effect of a soil-feeding termite, Cubitermes fungifaber (Isoptera: Termitidae) on soil properties: termites may be an important source of soil microhabitat heterogeneity in tropical forests. Pedobiologia, 45: 1-11. doi: 10.1078/0031-4056-00063.

Ehigiator, J.O., Okunima, E.D., Edosa, V.I. \& Airueghian, E. (2015). Use of termite mounds as an index of soil fertility and their effects on some properties of an environmentally degraded ultisols. Journal of Food, Agriculture and Environment, 13: 44-146. Retrieved from: http://world-food. net/download/2015-issue_3\&4-environment/e5.pdf.

Erens, H., Mujinya, B.B., Mees, F., Baert, G., Boeckx, P., Malaisse, F. \& Van Ranst, E. (2015). The origin and implications of variations in soil-related properties within Macrotermes falciger mounds. Geoderma, 249-250: 40-50. doi: 10.1016/j. geoderma.2015.03.003

Ezenwa, M.I.S. (1985). Comparative study of some chemical characteristics of mound materials and surrounding soils of different habitats of two termite species in Nigerian savanna. GEO-ECO-TROP, 9: 29-38.

Fageria, N.K. \& Baligar, V.C. (2004). Properties of termite mound soils and responses of rice and bean to nitrogen, phosphorus, and potassium fertilization on such soil. Communications in Soil Science and Plant Analysis, 35: 2097-2109. doi: 10.1081/ LCSS-200028919.

Garnier-Sillam, E. \& Harry, M. (1995). Distribution of humic compounds in mounds of some soil-feeding termite species of tropical rainforests: its influence on soil structure stability. Insectes Sociaux, 42: 167-185. doi: 10.1007/BF01242453.

Gholami, A. \& Riazi, F.(2012). Impact of termite activity on physical and chemical properties. Journal of Basic and Applied Scientific Research, 2:5 581-5582.

Gosling, C.M., Cromsigt, J.P.G.M., Mpanza, N. \& Olff, H. (2012). Effects of erosion from mounds of different termite genera on distinct functional grassland types in an African savannah. Ecosystems, 15: 128-139. doi: 10.1007/s10021011-9497-8.

Gupta, S.R., Rajvanshi, R. \& Singh, J.S.(1981). The role of the termite Odontotermes gurdaspurensis (Isoptera: Termitidae) in plant decomposition in a tropical grassland. Pedobiologia, 22: 254-261.

Jouquet, P., Tessier, D. \& Lepage, M. (2004). The soil structural stability of termite nests: role of clays in Macrotermes bellicosus (Isoptera, Macrotermitinae) mound soils. European Journal of Soil Biology, 40: 23-29. doi: 10.1016/j.ejsobi.2004.01.006.

Jouquet, P., Ranjard, L., Lepage, M. \& Lata, J.C. (2005). Incidence of fungus-growing termites (Isoptera, Macrotermitinae) on the structure of soil microbial communities. Soil Biology and Biochemistry, 7: 1852-1859. doi: 10.1016/j.soilbio.2005.02.017.

Jouquet, P., Guilleux, N., Caner, L., Chintakunta, S., Ameline, M. \& Shanbhag, R.R. (2016). Influence of soil pedological properties on termite mound stability. Geoderma, 262: 45-51. doi: 10.1016/j.geoderma.2015.08.020.

Kaschuk, G., Santos, J.C.P., Almeida, J.A., Sinhorati, D.C. \& Berton-Junior, J.F. (2006). Termite activity in relation to natural grassland soil attributes. Scientia Agricola, 63: 583588. doi: 10.1590/S0103-90162006000600013.

Ketch, L.A., Malloch, D., Mahaney, W.C. \& Huffmanc, M.A. (2001). Comparative microbial analysis and clay mineralogy of soils eaten by chimpanzees (Pan troglodytes schweinfurthii) in Tanzania. Soil Biology and Biochemistry, 33: 199-203.doi: 10.1016/S0038-0717(00)00129-2. 
Lee, K.E. \& Wood, T.G.(1971). Physical and chemical effects on soils of some Australian termites and their pedological significance. Pedobiologia, 11: 376-409.

López-Hernández, D. (2001). Nutrient dynamics (C, N and P) in termite mounds of Nasutitermes ephratae from savannas of the Orinoco Llanos (Venezuela). Soil Biology and Biochemistry, 33: 747-753. doi: 10.1016/S0038-0717(00)00220-0.

López-Hernández, D. \& Febres, A.(1984). Changements chimiques et granulométriques produits dans des sols de Côte d'Ivoire par la présence de trois espèces de termites. Revue d'Ecologie et de Biologie du Sol, 21: 477-489.

Mahaney, W.C., Zippin, J., Milner, M.W., Sanmugadas, K., Hancock, R.G.V., Aufreiter, S., Campbell, S., Huffman, M.A., Wink, M., Malloch, D. \& Kalm, V. (1999). Chemistry, mineralogy and microbiology of termite mound soil eaten by the chimpanzees of the Mahale Mountains, Western Tanzania. Journal of Tropical Ecology, 15: 565-588. doi: 10.1017/ S0266467499001029.

Malaka, S.L.O. (1977). A study of the chemistry and hydraulic conductivity of mound materials and soils from different habitats of some Nigerian termites. Australian Journal of Soil Research, 15: 87-91.

Ministry of Agriculture of the People's Republic of China. (2007). Determination of $\mathrm{pH}$ in soil. NY/T 1377-2007. Retrieved from: http://www.doc88.com/p-6522013917098. html.

Mujinya, B.B., Van Ranst, E., Verdoodt, A., Baert, G. \& Ngongo, L.M. (2010). Termite bioturbation effects on electrochemical properties of Ferralsols in the Upper Katanga (D.R. Congo). Geoderma, 158: 233-241. doi: 10.1016/j. geoderma.2010.04.033.

Mujinya, B.B., Mees, F., Boeckx, P., Bodé, S., Baert, G., Erens, H., Delefortrie, S., Verdoodt, A., Ngongo, M. \& Van Ranst, E.(2011). The origin of carbonates in termite mounds of the Lubumbashi area, D.R. Congo. Geoderma, 165: 95105. doi: 10.1016/j.geoderma.2011.07.009.

Muvengwi, J., Mbiba, M. \& Nyenda, T.(2013). Termite mounds may not be foraging hotspots for mega-herbivores in a nutrient-rich matrix. Journal of Tropical Ecology, 29: 551558.doi: 10.1017/S0266467413000564.

Neupane, A., Maynard, D.S. \& Bradford, M.A. (2015). Consistent effects of eastern subterranean termites (Reticulitermes flavipes) on properties of a temperate forest soil. Soil Biology and Biochemistry, 91: 84-91.doi: 10.1016/j.soilbio.2015.08.025

Nutting, W.L., Haverty, M.I. \& La Fage, J.P. (1987). Physical and chemical alteration of soil by two subterranean termite species in Sonoran Desert grassland. Journal of Arid Environments, 12: 233-239.

Nye, P.H. (1955). Some soil forming processes in the humid tropics. IV. The action of soil fauna. Journal of Soil Science, 6: 73-83. doi: 10.1111/j.1365-2389.1955.tb00831.x.

Okello-Oloya, T., Spain, A.V. \& John, R.D. (1985). Selected chemical characteristics of the mounds of two species of Amitermes (Isoptera, Termitinae) and their adjacent surface soils from north eastern Australia. Revue d'Ecologie et de Biologie du Sol, 22: 291-311.

Okwakol, M.J.N. (1987). Effects of Cubitermes testacus (Williams) on some physical and chemical properties of soil in a grassland area of Uganda. African Journal of Ecology, 25: 147-153.

Park, H.C., Majer, J.D. \& Hobbs, R.J. (1994). Contribution of the Western Australian wheatbelt termite, Drepanotermes Tamminensis (Hill), to the soil nutrient budget. Ecological Research, 9: 351-356. doi: 10.1007/BF02348422.

Rao, A.N., Sravanthy, C.H. \& Sammaiah, C.H.(2013). Diversity and density of termite mounds in Bhadrachalam forest region, Andhra Pradesh. The Bioscan, 8: 1-10.

Robert, O.E., Frank, U.O. \& Agbonsalo, O.U. (2007). Influence of activities of termites on some physical and chemical properties of soils under different land use patterns: areview. International Journal of Soil Science, 2: 1-14.

Robinson, J.B.D. (1958). Some chemical characteristics of 'termite soils' in Kenya coffee fields. Journal of Soil Science, 9: 58-65. doi: 10.1111/j.1365-2389.1958.tb01897.x.

Roose-Amsaleg, C., Brygoo, Y. \& Harry, M. (2004). Ascomycete diversity in soil-feeding termite nests and soils from a tropical rainforest. Environmental Microbiology, 6: 462-469. doi: 10.1111/j.1462-2920.2004.00579.x.

Roose-Amsaleg, C., Mora, P. \& Harry, M. (2005). Physical, chemical and phosphatase activities characteristics in soilfeeding termite nests and tropical rainforest soils. Soil Biology and Biochemistry, 37: 1910-1917. doi: 10.1016/j. soilbio.2005.02.031.

Salick, J., Herrera, R. \& Jordan, C.F. (1983). Termitaria: nutrient patchiness in nutrient deficient rain forests. Biotropica, 15:1-7. doi: 10.2307/2387990.

Samra, J.S., Tandon, P.L., Thakur, R.S. \& Chadha, K.L. (1979). Comparison of physicochemical characteristics of the soils of termite galleries and the surrounding soil in mango orchards. Indian Journal of Agricultural Science, 49: 892-895.

Sarcinelli, T.S., Schaefer, C.E.G.R., Lynch, L.D.S., Arato, H.D., Viana, J.H.M., Filho, M.R.D.A. \& Gonçalves, T.T. (2009). Chemical, physical and micromorphological properties of termite mounds and adjacent soils along a toposequence in Zona da Mata, Minas Gerais State, Brazil. Catena, 76: 107-113. doi: 10.1016/j.catena.2008.10.001.

Sheikh, K.H. \& Kayani, S.A. (1982). Termite-affected soils in Pakistan. Soil Biology and Biochemistry, 14: 359-364. 
SPSS Inc. (2007). SPSS Base 16.0 for Windows User's Guide. Chicago: SPSS Inc. 736 p.

Su, N.-Y. (2002). Novel technologies for subterranean termite control. Sociobiology, 39: 1-7.

Su, N.-Y. \& Scheffrahn, R.H. (1998). A review of subterranean termite control practices and prospectsfor integrated pest management programmes. Integrated Pest Management Reviews, 3: 1-13. doi: 10.1023/A:1009684821954.

Tian W.J., Ke Y.L., Zhuang T.Y., Wang C.X., Li M., Liu R.Q., Mao W.G., Zhang S.S. \& Li, D. (2009). Incipient colony development and biology of Odontotermes formosanus (Shiraki) and $O$. hainanensis (Light) (Isoptera: Termitidae). Journal of Agricultural and Urban Entomology, 26: 147-156. doi: 10.3954/1523-5475-26.3.147.

Verma, M., Sharma, S. \&Prasad, R. (2009). Biological alternatives for termite control: a review. International Biodeterioration and Biodegradation, 63: 959-972. doi: 10.1016/j.ibiod.2009.05.009.
Watson, J.P. (1962). The soil below a termite mound. Journal of Soil Science, 13: 46-51. doi: 10.1111/j.1365-2389.1962. tb00680.x.

Watson, J.P. (1969). Water movement in two termite mounds in Rhodesia. The Journal of Ecology, 57: 441-451. doi: 10.23 $07 / 2258390$.

Watson, J.P. (1972). Some observations on the water relations of mounds of Macrotermes natalensis (Haviland) fuller. Insectes Sociaux, 19: 87-93. doi: 10.1007/BF02224726.

Watson, J.P. (1977). The use of mounds of the termite Macrotermes falciger (Gerstäcker) as a soil amendment. Journal of Soil Science, 28: 664-72.

Wood, T.G., Johnson, R.A. \& Anderson, J.M. (1983). Modification of soils in Nigerian savanna by soilfeeding Cubitermes (Isoptera, Termitidae). Soil Biology and Biochemistry, 15: 575-579. doi: 10.1016/00380717(83)90052-4.

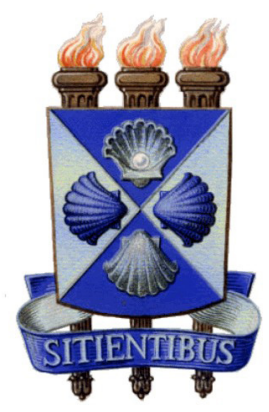

